\title{
Features of noun quantifiers in old Romanian
}

\author{
Camelia Stan* \\ Faculty of Letters, University of Bucharest, 5-7 Edgar Quinet St., 010017 Bucharest, Romania \\ "Iorgu Iordan - Al. Rosetti" Institute of Linguistics, 13 Calea 13 Septembrie, 050711 Bucharest, Romania
}

\section{Article info}

History:

Received May 18, 2017

Accepted June 4, 2017

Published September 30, 2017

Key words:

historical grammar

biblical text

old documents

\begin{abstract}
This study is part of a collective research on the historical morphology of Romanian, conducted at the Institute of Linguistics of the Romanian Academy in Bucharest. This analysis approaches in detail a specific issue in the diachrony of noun quantifiers, more precisely, the tendency towards internal fusion which compound ordinal numerals showed in old Romanian (the $16^{\text {th }}$ to $18^{\text {th }}$ centuries). The tendency towards formal unity determined certain changes in the morphology and syntax of numerals. Thus, the aim of this analysis is to highlight and explain the morphosyntactic manifestations of this process. Therefore, the forms of the numeral are discussed in relation to the syntactic structure of the quantified nominal phrase. The framework adopted here is the theory of grammaticalization, and contemporary diachronic syntax. The analysis of the old structures containing ordinal numerals allows us to formulate observations related to: the inflectional features of the ordinal numerals and their combination with articles, the grammaticalization degree of the formative $a$, the origin of the enclitic formatives $-l(u) /-l e /-l e a,-a$, and the ordering of these formatives.
\end{abstract}

\section{Introduction}

The structure of the quantified nominal phrases showed a high degree of formal variation in the old stage of Romanian, in the $16^{\text {th }}, 17^{\text {th }}$ and $18^{\text {th }}$ centuries, up until around 1780 , according to the largely accepted periodization in the Romanian literature (for the periodization proposed by Ion Gheție, see ILRL, p. 5253; ELR, s.v. veche, limbă $\sim$ ). The texts from that period attest nominal (especially substantival) constructions with different types of elements having a quantificational meaning and function: numerals, the pronominal quantifier toți 'all' (universal quantifier), pronominal quantifiers with a universal distributive quantificational value (fiecare 'each, every', fiece 'each, every', etc.), indefinite quantifiers (atîtia 'so many', cîțiva 'a few', mulți 'many', puțini 'few', unii 'some', etc.), negative quantifiers (nici un 'no'), nouns (such as mulțime 'lot', seamă 'lot' - o seamă de... 'a lot of'), etc.

Researchers have always paid attention to the morphological and/or syntactic features of the numerals and pronominal quantifiers in old Romanian, these features being discussed in the treaties devoted to the history of Romanian and in special studies, with different theoretical frameworks (see, among many others, Densusianu, 1938, p. 177-196, 392-393; Diaconescu, 1970, p. 252-253; Onu, în Rosetti et al., 1971, p. 121, 140, 272, 236, 282, 328; Gheție \& Mareș, 1974, p. 238-240; Rosetti, 1986, p. 498, 500-501; Frâncu, in ILRL, p. 129-131, 331-333; Frâncu, 2009, p. 67-83, 167, 285-295, 347; Ivănescu, 2000, p. 228-229; Todi, 2001, p. 55-57, 253-254; Guruianu, 2005, p. 71-74; Popa, 2007, p. 60-66; Vasiliu, 2007, p. 75-77, 79; Philippide, 2011, p. 452-460; Vieru, 2014, p. 69-75, 84-89; Minut, 2017, p. 4). These issues are also tackled in linguistic studies which accompany philological editions of certain old texts (see, among others, Drăganu, 1914, p. 128; Mareș, 1969, p. 81-82; Rizescu, 1971, p. 78-81; Costinescu, 1981, p. 139, 142-143; Buză \& Zgraon, 1982, p. 512-513; Chivu, 1982, p. 190; Chivu, 1993, p. 182-184; Chivu, 2008, p. 54-55; Georgescu, 1982, p. 401; Gheție, 1982, p. 310-311; Gheție \&

\footnotetext{
*Email address: camelia.stan@litere.unibuc.ro.
} 
Teodorescu, 1977, p. 104; Gheție \& Teodorescu, 2005, p. 44; Roman Moraru, 1982, p. 77-78; Tarantino, 1996, p. 172; Dragomir, 2006, p. 66-68; Pantaleoni, 2008, p. 75, 77-78; Dima, 2010, p. XXVII; Mazilu, 2012, p. 105-108; Crețu, 2013, p. 223-225; Chiosea, 2016, p. 100-105, 128; Minuț, 2016, p. CLIXCLXII). More recently, the features of the quantifiers of nouns were analysed from the perspective of the modern diachronic syntax (for example, by Stan, 2013, 2016; Pană Dindelegan, 2016).

In this paper, we will not review the observations made in the literature cited above and we will not discuss in its entirety the behaviour of quantifiers in old Romanian. These data and linguistic phenomena are well known.

What we aim to analyse in this paper is the way in which the old texts reflect the language dynamics across the period under study, the insights offered by the old texts with respect to the existence of certain tendencies in that period, and the data relevant from a diachronic perspective.

Of the aspects of the dynamics of the old language, here we will refer only to the tendency of compound ordinal numerals towards internal fusion. This tendency, which characterized the morphological make-up process, manifested itself not only morphologically, but also syntactically.

We will adopt the hypothesis that ordinal numerals are quantifiers (in the nominal phrase), given that, by expressing order in counting, they entail the existence of a plurality: the nominal phrase including a noun and an ordinal numeral is associated with the presupposition of the existence of a class (of individuals) to which the referent of the noun belongs (al doilea copil 'the second child [among two or more children]'; presupposition: 'there are at least two children').

In order to reach the aim of our research, we have compared two types of old texts: biblical texts and original documents (administrative, juridical, private, etc.). The old biblical text is above all conservative, rigidly canonical (not only dogmatically, but also from a linguistic perspective). By contrast, old original documents, although written following certain patterns, represent the closest linguistic variant to the current usage of the $16^{\text {th }}-18^{\text {th }} \mathrm{c}$. language (inaccessible directly to linguists, given the absence of spontaneous old language attestations).

The main biblical translations used as a source for our analysis are: Vechiul Testament - Septuaginta, the version of Nicolae Spătarul Milescu (Ms. 45, BAR Cluj), recently published as a philological edition, in 2016 (MVTs.1683-1686); for comparison, Biblia de la București (BB.1688, MLD.1688), a translation having the same Greek source as Nicolae Milescu's translation (Munteanu, 2016, p. LXII); Palia de la Orăștie (Po.1582) and, for comparison, the $17^{\text {th }}$ century copies of certain books from the Old Testament, translated in the $16^{\text {th }}$ century for Palia de la Orăștie, not printed at that time but published as a modern philological edition in 2009 (DvT.1679-1699); Cartea înțelepciunii lui Iisus, feciorul lui Sirah [Cîmpulung Muscel, c. 1665-1672], a text edited in 2005 (Cî̀fs.1655-1672).

The original documents used as a source for the $16^{\text {th }}$ century are the ones included in the Dî corpus. For the $17^{\text {th }}$ and $18^{\text {th }}$ centuries, we have used recently published documents, less explored, or even not examined at all from a linguistic perspective: CATASTIFE.1744-1745, CATASTIH.1732, CONDICĂ.17481751, DOC.ATHOS, DOC.DRAGOMIRNA, DOC.ŢR (vol. I-II).

\section{The forms and usage of compound ordinal numerals}

In old Romanian, the form and syntactic properties of the compound ordinal numerals were not fixed. From a diachronic perspective, the following aspects are relevant: the variation of the formatives $-l /-l e /$ -lea; the absence of the formatives $-l /-l e /-l e a,-a$; the ordering of these formatives; genitive-dative marking; the tendency towards the loss of the inflection; and the $c e l$ and the de constructions.

\subsection{Variation and absence of the formatives $-l /-l e /-l e a,-a$}

2.1.1. Densusianu (1938, p. 179) showed that, as far as the compound ordinal numerals containing al are concerned, the masculine form ending in -le, such as al doile 'the second' (Psaltirea Hurmuzaki), was more frequent in the $16^{\text {th }}$ century than the form ending in -lea, containing the final segment $-a$ after 
-le-: al doilea (Coresi's Cazania I). Densusianu also found masculine forms ending in $-l$ in texts from the same period: al optul 'the eighth' (for example, in Codicele Voronețean), al patrul 'the fourth' (in Coresi's Tetraevanghel, etc.).

The competition between the forms with and without the final deictic particle $-a$ is also discussed in the linguistic studies accompanying philological editions of texts (see, among many others, Mareș, 1969, p. 82; Chivu, 1993, p. 184; recently, Minuț, 2016, p. CLXI).

In a previous paper (Stan, 2016, p. 349), we have presented the results of an analysis regarding the number of occurrences of the old forms ending in -le and the new ones ending in -lea. This analysis revealed the presence of both types of forms in $16^{\text {th }} \mathrm{c}$. translations and original documents (the documents included in the corpus Dî). The old forms are more frequent in translations, whereas the new ones prevail in the original documents. The old forms in - l al optul 'the eighth' and al patrul 'the fourth' were attested in religious texts from the $16^{\text {th }}$ century and from the first half of the $17^{\text {th }}$ century; the form al patrul is also attested in the corpus Dî.

2.1.2. An interesting fact consists in the absence of the enclitic formatives of the ordinal numerals compound with al written as numbers: for the masculine, the formative -le/-lea is absent in (1a), whereas for the feminine the formative $-a$ is not present in $(1 b, c)$. In the context of the demonstrative $c e l$, the numerals have enclitic formatives: the formative $-a$ for the feminine, written with letters ( $1 \mathrm{~d})$; the formative $-l$ for the masculine, written with numbers (1e).

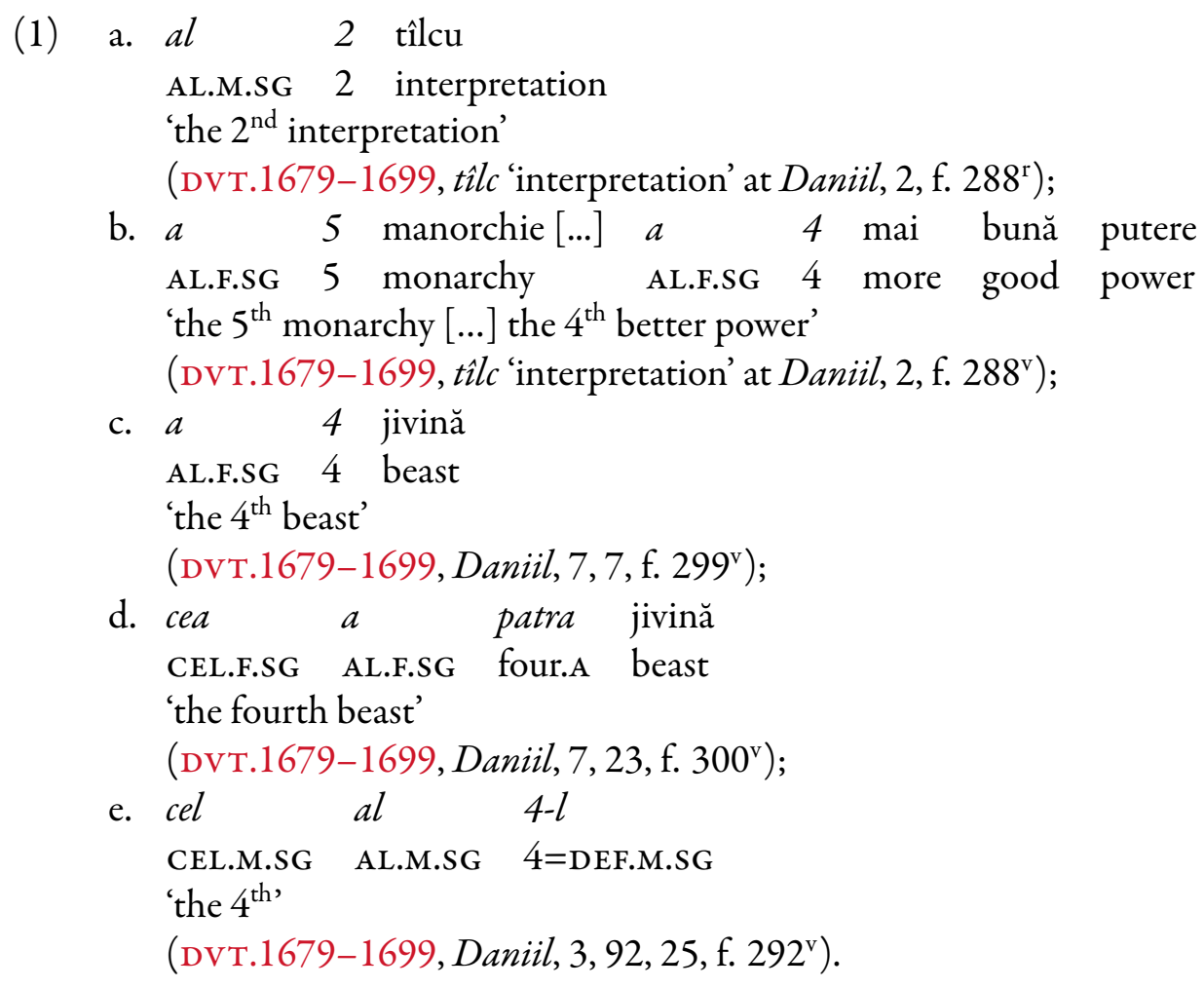

The presence of the enclitic formative $-l$ of ordinal numerals in the constructions with the $[+$ definite, + deictic] determiner $c e l$ becomes significant if we accept that $-l$, in the structure of old ordinal numerals, is etymologically related to the definite article $-l$ (for the etymological relation between the enclitic formative $-l u$, $-l e$ in the structure of the masculine ordinal numeral and the definite article, see ILR (II, p. 237-238); Rosetti (1986, p. 373). With the feminine forms, a patra 'the fourth' (1d), the deictic enclitic element $-a$ corresponds not only to the formative $-l$ or $-l e$, but also to the deictic particle $-a$ in the masculine forms. The co-occurrence of $c e l$ and the enclitic formative $-l$ in (1e) can be thus explained through their common features. We cannot ascertain whether for the speakers of old Romanian - $l$ expresses definiteness in the numerals al optul 'the eighth', al patrul 'the fourth'; any semantic interpretation of these facts 
cannot be documented and therefore it would be speculative and exaggerated. However, the structures al optul, al patrul are very similar to the masculine nouns articulated with the definite article $-l$. For that reason, we cannot exclude the analogy with the definite article. The compound ordinal numerals with al are intrinsically definite, because al etymologically incorporates the definite article (for the etymological explanation, see DELR, s.v. al and the references therein). Cel also etymologically incorporates the definite article (DELR, s.v. acel, cel and the references therein). Thus, the selection of the enclitic formative of the ordinal numeral in the structures with the $[+$ definite, + deictic] determiner cel most probably had an etymological basis.

An aspect relevant for the distribution of the enclitic feminine formative $-a$ appears in Nicolae Milescu's MVTs.1683-1686. Minuț (2016, p. CLXI) has shown that the feminine ordinal numerals derived from 11-19 are used (written with letters) with or without the final particle $-a$. The examples quoted by this author and other examples from Milescu's text suggest that the variation was, to a certain extent, conditioned by syntactic structure. One may notice a preference for the forms ending in $-a$ before a feminine noun without a definite article $(2 \mathrm{a}, \mathrm{b})$; in contrast, $-a$ could not be expressed after a feminine noun bearing the enclitic definite article $-a(2 c, d)$. The distribution of the forms is not consistent, however $(2 \mathrm{e})$. The distribution of the enclitic formative $-a$ in $(2 a-d)$ is similar to the distribution of the enclitic article in the patterns of the nominal phrase which survived in modern Romanian: the definite articles always attaches to the first constituent of the nominal phrase, that is to the noun or to the prenominal adjective: luna următoare (month.DEF.F.SG next 'the next month'), următoarea lună (next.DEF.F.SG month 'the next month'). In the same way, the deictic particle $-a$ attaches to the preposed ordinal numeral $(2 a, b)$ but is absent from the structure of the numeral after a noun bearing the enclitic definite article $-a(2 c, d)$.

(2) a. în doaosprădzêcea lună

in twelve.F.SG.A month

'in the twelfth month'

(MVTS.1683-1686, Est, 9, 1, p. 420);

b. în a treispräzêcea a al

in AL.F.SG thirteen.A of AL.M.SG twelve.F.SG.A month

'in the thirteenth of the twelfth month'

(MVTs.1683-1686,2Mac, 15, 37, p. 881);

c. în dzua a doaosprădzêce

in day.DEF.F.SG AL.F.SG twelve.F.SG

'in the twelfth day'

(MVTs.1683-1686, Num, 7, 78, p. 125);

d. întru luna a doaosprăzêce

in month.DEF.F.SG AL.F.SG twelve.F.SG

'in the twelfth month'

(MVTs.1683-1686, Iez, 32, 1, p. 653);

e. în a patrusprădzêce $d z i$

in AL.F.SG fourteen day

'in the fourteenth day'

(MVTS.1683-1686, Ieş, 18, p. 62).

In $(2 \mathrm{a})$, the ordinal numeral marker $a(l)$ is missing. In $(2 \mathrm{e})$, the final segment $-a$, placed before the noun without a definite article, is missing.

Other decimal feminine numerals are also attested without the final $-a$, before the noun without a definite article:
(3) întru a
cincidzeci
sărbătoare
in
AL.F.SG fifty
holiday 
'in the fiftieth holiday'

(MVTs.1683-1686, Tovit, 2, 2, p. 728).

Moreover, the formative -lea could be left out when the numeral was written in letters:

(4) anul

al optsprădzêce

year.DEF.M.SG AL.M.SG eighteen

'the eighteenth year'

(MVTs.1683-1686, Ier, 32, 1, p. 600).

In DVT.1679-1699, the numerals written in numbers, without the final formative, are attested not only in the translation of the biblical text (1c), but also in the parts containing the 'interpretation' $(1 \mathrm{a}, \mathrm{b})$.

The absence of the final formatives of the ordinal numerals written with numbers can be also noticed in the unpublished books of the Palia (DVT.1679-1699), but also in its published parts (PO.1582). This fact was thrown into light by Vieru (2014, p. 71), in relation to Palia; the author has shown that when ordinal numerals are written with numbers, the formatives $-l e /-l e a$ are not written (5).

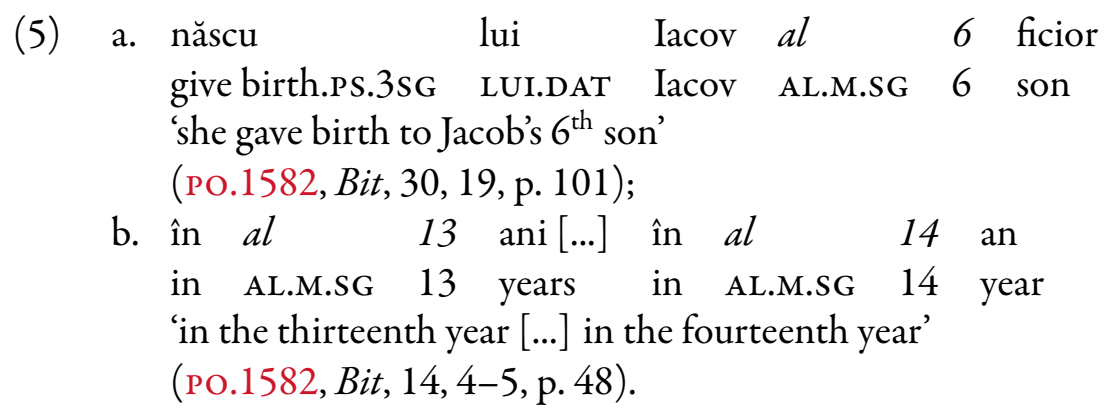

In DVT.1679-1699, the final formative $-l$ is expressed after the numeral written with numbers (1e).

The absence of the final formatives of the compound ordinal numerals with al in the books of Palia (PO.1582, DVT.1679-1699) is not just a simplification of the writing with numbers. This type of notation always contains the formative al, whereas the enclitic formative is generally absent. We believe that this fact indicates a difference between the formatives with respect to their degree of fusion, in the numerical writing: the text reflects a stage of the language in which al and the base of the compound (the cardinal numeral incorporated as the root of the ordinal numeral and written with numbers) were more highly fused than the enclitic formatives and the base. $A l$ already functioned as a marker of the ordinal numeral (viz. the cardinal numeral), and therefore it could not be omitted when the numerical writing was used. $A l$ was an entirely grammaticalized functional element, specialized as a marker of the ordinal numeral. It might be the case that, in certain situations, the enclitic formatives and $a l$ were redundant: especially for the numerical writing in ( $1 \mathrm{a}, \mathrm{b}, \mathrm{c}),(5)$, in which $a l$ is variable and it encodes, by its shape (al, masculine; $a$, feminine), the gender inflectional distinction of the numeral, the enclitic markers - $l /-l e /-l e a$ (masculine), $-a$ (feminine) were supplementary marking, in a redundant way, the gender distinction and therefore they could be dropped.

Structures such as al 2 (1a) are rare in the original documents (6) and have not been preserved in the present-day language.

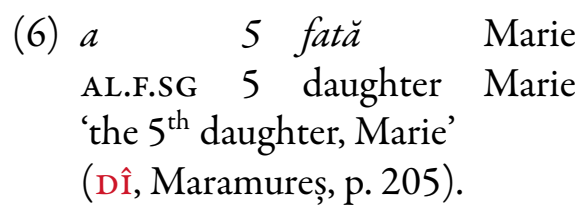

The presence of $a l$ in the numerical notation used in the biblical style (a highly conservative register) in the $16^{\text {th }}$ century indirectly suggests that the grammaticalization of $a l$ in the structure of the ordinal numeral was accomplished in an older period.

The $16^{\text {th }}$ century texts only present formal variation related to the enclitic formatives. 


\subsection{The ordering of the formatives}

Densusianu (1938, p. 180) registered, in the $16^{\text {th }}$ century translations, feminine forms of the ordinal numeral such as a dooasprădzece (AL.F.SG two.F.SG-A-upon-ten 'the twelfth'; Psaltirea Voronețeană), with the formative $-a$ attached not enclitically, at the end of the compound [(2a): doaosprădzêcea - two.F.SGupon-ten-A], but after its first component (doo - two.F.SG).

This type of forms also appears in later texts. The presence of these structures in biblical texts has been more recently discussed by Popa $(2007$, p. 66), with respect to the Book of the Apostles from Noul Testament de la Bălgrad, 1648 (for exemple, a patrasprăzeace - AL.F.SG four-A-upon-ten 'the fourteenth'), in comparison to Biblia de la București, 1688 (a patrusprăzeace - AL.F.SG four-upon-ten 'the fourteenth', without final $-a)$.

The structure in (7a) attests a complex situation, in which the position of the formative -lea influences the syntactic properties of the numeral.
a. acesta al
patruzecilea si
cinci de ani
this AL.M.sG forty.LEA and five of years

(lit.) 'this $40^{\text {th }}$ and five of years' (i.e. 'this forty-fifth year')

(Bв.1688, Iisus Navi, 14, 10, p. 163);

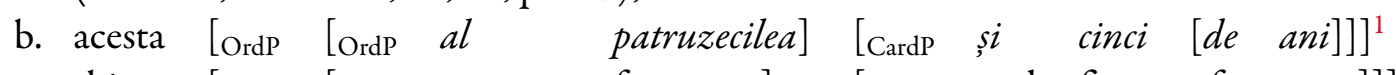
this [OrdP [OrdP AL.M.SG forty.LEA $]$ [CardP and five of years]]].

In the structure of the ordinal numeral derived from patruzeci si cinci (lit. 'forty and five', i.e. 'forty-five'), the masculine formative -lea attaches to the first constituent. The form al patruzecilea (AL.M.SG forty.LEA 'the fortieth') has the structure of an ordinal numeral. The sequence și cinci ('and five') correspond to the final part of the cardinal numeral patruzeci și cinci (lit. 'forty and five'). The sequence și cinci associates the syntactic properties of a cardinal numeral to the construction al patruzecilea și cinci (lit. 'the fortieth and five'). This is what accounts the fact that the quantified noun ani 'years' (corresponding to the construction of the cardinal numeral: patruzeci și cinci de ani - lit. 'forty-five of years', i.e. 'forty-five years') is linked by means of the preposition de 'of'. The ordinal numeral al patruzecilea și cinci ('the fortieth and five') has an anacoluthon-like internal structure, represented in $(7 \mathrm{~b})$. The second anacoluthon is represented by the lack of number agreement in the nominal phrase: the demonstrative determiner acesta 'this' and the ordinal numeral al patruzecilea 'the fortieth' are singulars, whereas the noun ani 'years' has a plural form (required by the cardinal numeral patruzeci si cinci 'forty and five', the base of the anacoluthon-like ordinal numeral al patruzecilea și cinci 'the fortieth and five').

In (8), the position of the formative -lea is similar to the one in (7a):

(8) anul al doaodzecilea și patru

year.DEF.M.sG AL.M.sG twenty.LEA and four

(lit.) 'the year the twentieth and four' (i.e. 'the twenty-fourth year')

(MVTs.1683-1686, 3Reg, 15, 8, p. 302).

In (9), the formative -lea attaches to the first constituent, in an inverted anacoluthon-like structure, whereas the noun $a i$ 'years' is linked by means of the preposition de 'of':

(9) întru al șaptelea și doadzeci de ai in AL.M.SG seven.LEA and twenty of years

(lit.) 'in the seventh and twenty of years' (i.e. 'in the twenty-seventh year')

(MVTs.1683-1686, Iez, 29, 17, p. 651).

\footnotetext{
${ }^{1}$ When representing the syntactic structure $(7 \mathrm{~b})$, we have used the formal conventions of the generative grammar: we delimited the syntactic phrases using brackets; the symbol CardP refers to the cardinal phrase, whereas the symbol OrdP refers to the ordinal phrase.
} 
The compound-internal position of the formatives -lea, $-a$, specific to ordinal numerals, suggests a lower degree of fusion of the numeral. The enclitic formatives -lea, $-a$ suggest a higher degree of internal fusion, they are regularly found in the original documents since the $16^{\text {th }}$ century (al doozecilea - AL.M.SG twenty.LEA 'the twentieth'; Dî.1599, p. 115), and they have been preserved in the modern language.

\subsection{Inflection: genitive-dative case marking; tendency towards the loss of inflection}

2.3.1. In the nominal phrase including an ordinal numeral, the genitive-dative case could be encoded just once, in the structure of the noun (10a), or could be redundant, the enclitic morphemes being attached to the noun and to the preposed numeral (10b); Vieru (2014, p. 72) has recently discussed the structures from Palia de la Orăștie:
a. în dzi dentîi al zeace luniei
in day first AL.M.SG ten month.SG.GEN.DEF.SG.GEN
'in the first day of the tenth month' (po.1582, Bit, 8, 5, p. 32);
b. al șeptei luniei
AL.M.SG seven.DEF.SG.GEN month.SG.GEN.DEF.SG.GEN
'of the seventh month'
(Po.1582, Bit, 8, 4, p. 32).

The case of the numeral is encoded, in (10b), by the genitive-dative form of the enclitic article.

The pattern which has been preserved is the one in which the case of the ordinal numeral is encoded in the form of the preposed determiner $c e l$ :

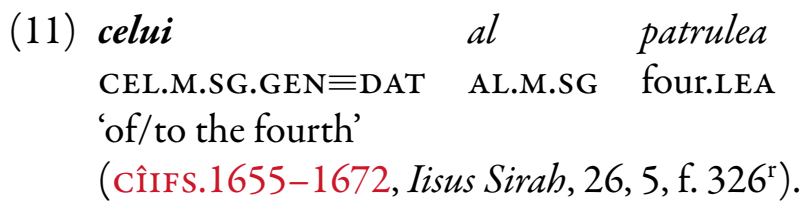

The preference of later authors, such as Stolnicul Constantin Cantacuzino, for the old forms, with the enclitic article, of the ordinal numeral in genitive-dative, against the new ones, with cel, stems from the fact that the old forms were stylistically marked, they offered an archaic flavour to the text and they used to characterize the formal register:
cărți a lui
book.F.SG.GEN of his
'in the third section of his second book'
(CIst.1700-1750, f. 24 $4^{\mathrm{r}}$ );
a. într-a treia
decadă $a \quad a$
doauăi
in=AL.F.SG three.A section of AL.F.SG two.F.DEF.F.SG.GEN
b. într-a doua decadă $a$ a patrai cărţi
in=AL.F.SG two.A section of AL.F.SG four.A.DEF.F.SG.GEN book.F.SG.GEN
'in the second section of the fourth book'
(CIst.1700-1750, f. 30 r).

The structures with $\mathrm{cel}$ were specific, in the old language as in the present-day language, to the formal, elaborate register. They are not specific to the administrative documents included in the corpora CATASTIFE.1744-1745, CATASTIH.1732, CONDICĂ.1748-1751, DOC.ATHOS, DOC.DRAGOMIRNA, DOC.ȚR (vol. I-II).

2.3.2. The structures with an unmarked nominal phrase in the genitive-dative in translations are due to the Greek influence. The relevant examples are found in Nicolae Milescu's translations (Minuţ, 2016, p. CLXII), not only from biblical texts (13), but also from other translations of his (14): 
(13) numele al doilea rîu

name.DEF AL.M.SG two.LEA river

'the name of the second river'

(MVTS.1683-1686, Fac, 2, 13, p. 3; modern Romanian celui de al doilea rîu);

(14) svîrșitul al doile cuvînt

end.DEF AL.M.SG two.LE oration

'the end of the second oration'

(ICP 1700, f. $141^{\mathrm{r}}$; modern Romanian celei de a doua orații).

However, the pattern is not attested in translations belonging to other registers such as Epistolăsipanegiric greco-român adresate lui Constantin Brîncoveanu (Ms. BAR 766), a text recently published in a modern philological edition (EP.1692-1697).

2.3.3. The old plural forms of the numeral ordinal, ai treii (AL.M.PL three.PL; Densusianu, 1938, p. 179), with number encoded in the form of the functional element $a l$ and in the form of the enclitic article attached to the numeral, have not been preserved. The loss of inflectional number distinctions and the lexicalization of the ordinal numeral as an invariable singular form are correlated with an increasingly tighter formal unity.

\subsection{The construction with cel and de}

The ordinal numeral intîi 'first' from the structures with $c e l$ used to be employed in the compound dintîi, which contains the preposition de (Densusianu, 1938, p. 179):

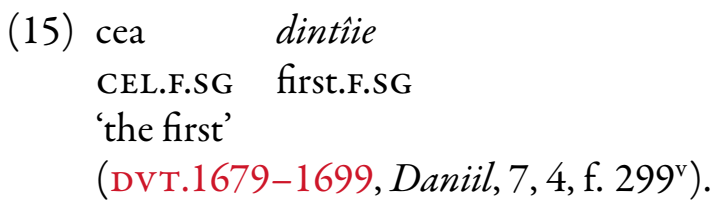

As for the ordinal numerals containing $a l$, the structures with $d e$ (which were preserved in the language): cel de al doilea (CEL.M.SG DE AL.M.SG two.LEA 'the second') and the ones without de (11), (16) were in variation during the entire old period.
a. cel
al triilea
CEL.M.SG
AL.M.SG three.LEA
'the third'
(MVTs.1683-1686, Iosip, 10, 1, p. 900);
b. cel al treilea
CEL.M.SG AL.M.SG three.LEA
'the third'
(MLD.1688, Iosip, 10, 1, p. 54).

The structures with de were less fused in the old language than they are in the present-day language, a fact supported by their alternation with the structures without $d e$, namely by the possibility to choose between the two constructions. In the present-day language, the structure with de has a certain formal unity, de being obligatorily inserted in the presence of cel. However, the preposition de is not fused with the numeral, in contrast to the compound dintîi 'first'. 


\section{Conclusions}

Our analysis revealed some aspects related to the tendency toward internal fusion of the ordinal numerals in old Romanian.

Our research is based on data extracted from certain biblical translations and from original documents. The biblical texts under analysis (from the $16^{\text {th }}$ and the $17^{\text {th }}$ centuries) attest old forms and structures, which were probably anachronistic in that period and do not appear in documents, texts closer to the current linguistic usage. Thus, the original documents represented the reference point of our analysis. The comparison between the conservative biblical language and the language of the documents lead us to notice certain changes in the grammatical behaviour of ordinal numerals.

The sources analysed offer interesting hints for revisiting certain issues such as: the stage of grammaticalization of the marker $a l$ at the beginning of the old period or the origin of the enclitic formatives $-l(u) /-l e /-l e a,-a$ from the structure of the ordinal numeral.

Our analysis has also led to some detailed observations related to the position of the formatives, to the inflection of the ordinal numeral and to its compatibility with the article in old Romanian.

In the old original documents, ordinal numerals are very rare, the numerical values being generally expressed by cardinal numerals.

\section{Bibliography}

\section{A. Corpus}

вв.1688 = Biblia adecă Dumnezeiasca Scriptură a Vechiului și Noului Testament, tipărită întîia oară la 1688 în timpul lui Șerban Vodă Cantacuzino, Domnul Țării Românești, Editura Institutului Biblic, București, 1977.

CATASTIFE.1744-1745 = Lazăr, G. (ed.) (2015). 8 documents, in Iacob, D.D. (ed.), Avere, prestigiu și cultură materială în surse patrimoniale. Inventare de averi din secolele XVI-XIX, Editura Universității „Alexandru Ioan Cuza”, Iași, p. 488-521.

CATASTIH.1732 = Bedreag, E. (ed.) (2015). Document [BAR, Documente istorice, nr. 1129/126, orig. rom., 38 f.], in Iacob, D.D. (ed.), Avere, prestigiu și cultură materială in surse patrimoniale. Inventare de averi din secolele XVI-XIX, Editura Universităţii „Alexandru Ioan Cuza”, Iași, p. 166-200.

CIst. $1700-1750$ = Stolnicul C. Cantacuzino, Istoriia Țărîi Rumânești [1700-1750; v. SOR, p. 641], ed. O. Dragomir, Editura Academiei Române, București, 2016.

Cîrfs.1655-1672 = Bălan-Mihailovici, A. (ed.) (2005). Cartea înțtelepciunii lui Iisus, feciorul lui Sirah [Cîmpulung Muscel, c. 1665-1672], Editura Sinergii, Cîmpulung Muscel.

CONDICĂ.1748-1751 = Mârza, M. (ed.) (2015). Document [Arhivele Naționale din Iași, Manuscrise, nr. 1705, 34 f.], in Iacob, D.D. (ed.), Avere, prestigiu şi cultură materială în surse patrimoniale. Inventare de averi din secolele XVI-XIX, Editura Universității „Alexandru Ioan Cuza”, Iași, p. 216-251.

Dî = Mareș, Al. et al. (1979). Documente și insemnări românești din secolul al XVI-lea, Editura Academiei Române, București. DOC.ATHOS = Zahariuc, P. \& Marinescu, Fl. (eds) (2010). Documente româneşti din arbiva Mănăstirii Xenofon de la Muntele Athos, Editura Universității „Alexandru Ioan Cuza”, Iași, p. 51-103.

DOC.DRAGOMiRna = Iufu, I. \& Brătulescu, V. (eds) (2012). Manuscrise slavo-române din Moldova. Fondul Mănăstirii Dragomirna, Editura Universității „Alexandru Ioan Cuza”, Iași.

DOC.ȚR = Lazăr, G. (ed.) (2013-2014). Documente privitoare la negustorii din Țara Românească, I: 1656-1688; II: 16891714, Editura Universităţii „Alexandru Ioan Cuza”, Iași.

DVT.1679-1699 = Dima, C.-I. (2009). O traducere inedită a Vechiului Testament din secolul al XVI-lea [Crișana, Bihor, 16791699; ms. rom. 130, BAR], Editura Universității din București, București.

EP.1692-1697 = Chiosea, S. (ed.) (2016). Epistolă și panegiric greco-român adresate lui Constantin Brîncoveanu (Ms. BAR 766), Editura Universităţii „Alexandru Ioan Cuza”, Iaşi.

ICP 1700 = Ioan Cantacuzino, Patru apologii pentru religia creștinăși Patru orații. Traduse in limba română la mijlocul secolului al XVII-lea de Nicolae Spătarul (Milescu), ed. E. Dima, Editura Universităţii „Alexandru Ioan Cuza”, Iaşi, 2010.

MLD.1688 = Munteanu, E. (coord.) (2012). Monumenta linguae Dacoromanorum. Biblia 1688. Pars XXII, Iosephus ad Machabaeos, Editura Universității „Alexandru Ioan Cuza”, Iași.

MVTs.1683-1686 = Munteanu, E. (coord) (2016). Vechiul Testament - Septuaginta, Versiunea lui N. Spătarul Milescu [16831686] (Ms. 45, BAR Cluj), Editura Universității „Alexandru Ioan Cuza”, Iaşi.

po.1582 = Pamfil, V. (ed.) (1968). Palia de la Orăștie, Editura Academiei Române, București. 


\section{B. References}

Arvinte, V. (2006). Calcuri lingvistice în cartea Ieșirea (PO, BB, ms. 45, ms. 4389), in Arvinte, V., Studii de istorie a limbii române, Editura Universității „Alexandru Ioan Cuza”, Iași, p. 459-462 [published before in ALIL, vol. XXXII, 1988-1991, p. 25-28].

Buză, E. \& Zgraon, F. (1982). Studiu lingvistic to Prefețe și epiloguri din secolul al XVI-lea, in TR, p. 487-548.

Chiosea, S. (2016). Studiu lingvistic, in Chiosea, S. (ed.), Epistolă și panegiric greco-român adresate lui Constantin Brîncoveanu (Ms. BAR 766), Editura Universității „Alexandru Ioan Cuza”, Iași, p. 43-212.

Chivu, Gh. (1982). Studiu lingvistic to Pravila lui Coresi [Brașov, c. 1560-1562], in TR, p. 162-212.

Chivu, Gh. (1993). Studiu lingvistic, in Chivu, Gh. (ed.), Codex Sturdzanus [c. 1583-1619], Editura Academiei Române, București, p. 142-230.

Chivu, Gh. (2008). Studiu lingvistic, in Chivu, Gh. (ed)., Dictionarium valachico-latinum [Anonymus Caransebesiensis, 1650], Editura Academiei Române, București, p. 36-62.

Costinescu, M. (1981). Studiu lingvistic, in Costinescu, M. (ed.), Codicele Voronețean [1563-1583], Editura Minerva, București, p. 89-213.

Crețu, C. (2013). Studiu lingvistic, in Ilie Miniat, Cazanii (București, 1742), ed. C. Crețu, Editura Universității „Alexandru Ioan Cuza", Iași, p. 129-268.

DELR = Sala, M. \& Avram, A. (coord.) (2011-2015). Dicționarul etimologic al limbii române, I-II, Editura Academiei Române, București.

Densusianu, O. (1938). Histoire de la langue roumaine, II, Librairie E. Leroux, Paris.

Diaconescu, P. (1970). Structură și evoluție în morfologia substantivului românesc, Editura Academiei Române, București.

Dima, E. (2010). Studiu introductiv, in Ioan Cantacuzino, Patru apologii pentru religia creștinăşi Patru oraţii. Traduse în limba română la mijlocul secolului al XVII-lea de Nicolae Spătarul (Milescu), ed. E. Dima, Editura Universităţii „Alexandru Ioan Cuza”, Iași, p. VII-XLIX.

Dragomir, O. (2006). Studiu lingvistic, in Dragomir, O. (ed.), Istoriia Țărîi Rumâneşti atribuită stolnicului Constantin Cantacuzino, Editura Academiei Române, București, p. 39-135.

Drăganu, N. (1914). Particularitățile de limbă ale Codicelui Todorescu, in Drăganu, N. (ed.), Două manuscripte vechi: Codicele Todorescu și Codicele Marțian, Librăriile Socec și C. Sfetea, București, p. 89-166.

ELR = Sala, M. (ed.) (2001). Enciclopedia limbii române, Editura Univers Enciclopedic, București.

Frâncu, C. (2009). Gramatica limbii române vechi (1521-1780), Casa Editorială Demiurg, Iași.

Georgescu, M. (1982). Studiu lingvistic to Glosele Bogdan, in TR, p. 385-417.

Gheție, I. (1982). Studiu lingvistic to Fragmentul Todorescu [Cluj, c. 1571-1575], in TR, p. 285-331.

Gheție, I. \& Mareș, Al. (1974). Graiurile dacoromâne în secolul al XVI-lea, Editura Academiei Române, București.

Gheție, I. \& Mareș, Al. (1985). Originile scrisului în limba română, Editura Științifică și Enciclopedică, București.

Gheție, I. \& Teodorescu, M. (1977). Studiu de limbă, in Gheție, I. \& Teodorescu, M. (eds), Manuscrisul de la Ieud, Editura Academiei Române, București, p. 59-141.

Gheție, I. \& Teodorescu, M. (2005). Studiu lingvistic, in Gheție, I. \& Teodorescu, M. (eds), Psaltirea Hurmuzaki, I, Editura Academiei Române, București, p. 23-75.

Guruianu, V. (2005). Sintaxa textelor românești originale din secolul al XVI-lea. Sintaxa propoziției, Editura Universității din București. [București].

ILR = Coteanu, I. (ed.) (1969). Istoria limbii române, II, Editura Academiei Române, București.

ILRL = Gheție, I. (ed.) (1997). Istoria limbii române literare. Epoca veche (1532-1780), Editura Academiei Române, București.

Ivănescu, G. (2000). Istoria limbii române, $2^{\text {nd }} \mathrm{ed}$. [1 ${ }^{\text {st }} \mathrm{ed} .:$ 1980], Editura Junimea, Iași.

Mareș, Al. (1969). Studiu de limbă, in Mareș, Al. (ed.), Liturghierul lui Coresi [Brașov, 1570], Editura Academiei Române, București, p. 47-118.

Mazilu, I. (2012). Studiu lingvistic, in [Eustratie logofătul], Șeapte taine a besearecii, Iași, 1644, ed. I. Mazilu, Editura Universității „Alexandru Ioan Cuza”, Iași, p. 41-159.

Minuţ, A.-M. (2016). Studiu asupra morfologiei din Ms. 45, in MVTs.1683-1686, p. CXIII-CCIX.

Minuț, A.-M. (2017). Elemente de morfologie istorică românească, pe baza primei traduceri în limba română a Septuagintei (ms. 45, BAR Cluj), in "Diacronia", 5, March 23, art. A66, Crossref.

Munteanu, E. (2016). Studiu filologic, in MVTs.1683-1686, p. XLI-LXXVII.

Pană Dindelegan, G. (2016). The partitive phrase, in soR, p. 323-332, Crossref.

Pantaleoni, D. (2008). Morfologia, in Pantaleoni, D. (ed.), Texte românești vechi cu alfabet latin: Psalterium Hungaricum în traducere anonimă din secolul al XVII-lea, Editura Universității de Vest, [Timișoara], p. 73-78.

Philippide, Al. (2011). Istoria limbii române [ms., 1893-1932], ed. G. Ivănescu, C.- G. Pamfil, L. Botoşineanu, Editura Polirom, [Iași].

Popa, E.-C. (2007). Studiu lingvistic asupra cărții Faptele Apostolilor din Biblia de la București (1688) în comparație cu Noul Testament de la Bălgrad (1648) și cu Biblia de la Blaj (1795), Casa Editorială Demiurg, Iași. 
Rizescu, I. (1971). Studiu de limbă, in Rizescu, I. (ed.), Pravila ritorului Lucaci [1581], Editura Academiei Române, București, p. 35-145.

Roman Moraru, A. (1982). Studiu lingvistic to Catehismul lui Coresi [Brașov, c. 1560], in TR, p. 56-97.

Rosetti, A. (1986). Istoria limbii române, I. De la origini până la începutul secolului al XVII-lea, revised edition [1 ${ }^{\text {st }}$ ed.: 1938], Editura Științifică și Enciclopedică, [București].

Rosetti, A., Cazacu, B. \& Onu, L. (1971). Istoria limbii române literare, $2^{\text {nd }}$ ed., Editura Minerva, București.

SOR = Pană Dindelegan, G. (ed.) (2016). The Syntax of Old Romanian, Oxford University Press, Oxford, Crossref.

Stan, C. (2013). O sintaxă diacronică a limbii române vechi, Editura Universității din București, București.

Stan, C. (2016). (Numerical and non-numerical) quantifiers; quantifying approximators, in soR, p. 346-356, Crossref.

Tarantino, A. (1996). Le strutture linguistiche, in Tarantino, A. (ed.), La storia di Filerot e Anthusa. Istoria lui Filerot și cu a Anthusei (ms. 1374, BAR - Bucarest), Bagatto Libri, Roma, p. 115-187.

Todi, A. (2001). Elemente de sintaxă românească veche, Editura Paralela 45, Pitești/București/Brașov/Cluj-Napoca.

TR = Gheție, I. (coord.) (1982). Texte românești din secolul al XVI-lea, Editura Academiei Române, București.

Vasiliu, L. (2007). Atributul, in Avram, M. (ed.), Sintaxa limbii române în secolele al XVI-lea - al XVIII-lea, Editura Academiei Române, București, p. 73-109.

Vieru, R. (2014). Studiu lingvistic asupra Paliei de la Orăştie, Editura Universității „Alexandru Ioan Cuza”, Iași. 